\title{
Seasonal reproductive biology of the small cyclopoid copepod Oithona davisae in a temperate eutrophic inlet
}

\author{
Shin-ichi Uye, Kazuhiro Sano \\ Faculty of Applied Biological Science, Hiroshima University, Higashi-Hiroshima 724, Japan
}

\begin{abstract}
The seasonal variation in reproductive rate of the small cyclopoid Oithona davisae was investigated in a eutrophic inlet of the Inland Sea of Japan. The densities of its adults and copepodites were low in late winter and spring, and high in early summer and fall. A decline of the population in mid summer coincided with the occurrence of the lobate ctenophore Bolinopsis mikado. Adult sex composition was highly skewcd for females (annual mean: $85 \%$ ), particularly in winter $(96 \%)$. Female prosome length changed inversely with temperature, while egg diameter did not change throughout the year The variation in clutch size of ovigerous females was bicyclical, with peaks in early summer and fall. The duration of egg development was temperature dependent, while the time from hatching of egg sacs to production of new ones was uniform $(0.75 \mathrm{~d})$ and independent of temperature. The egg production rate of breeding $O$. davisae was high (mean: 11.6 eggs female $e^{-1} \mathrm{~d}^{-1}$, or a carbon weight-specific rate of $0.39 \mathrm{~d}^{-1}$ ) in early summer, and low (mean: 2.6 eggs female ${ }^{-1} \mathrm{~d}^{-1}$, or $0.08 \mathrm{~d}^{-1}$ ) in winter. Since there were considerable numbers of non-breeding females in the population, the egg proctuction rate on a population average was lower than the above-mentioned rate. The specific egg production rate of reproductive females increased linearly with increasing temperature up to ca $22^{\circ} \mathrm{C}$, but at temperatures $>22^{\circ} \mathrm{C}$, the rate did not change or was even reduced. The reduction in the rate was remarkable in fall, indicating females' physiological stress in this season.
\end{abstract}

KEY WORDS: Cyclopoid copepod Egg production - Oithona - Inland Sea of Japan

\section{INTRODUCTION}

Oithonids are the most successful free-living cyclopoids in the marine pelagic ecosystem. They are small, usually $<1.0 \mathrm{~mm}$ in body length, but they occur in all parts of the world ocean at relatively high numerical densities (Nishida 1985). Compared to the vast information on the population dynamics and production of marine calanoid copepods, few studies have been made for marine cyclopoid copepods, and hence our understanding of the functional roles of the cyclopoid copepods in the marine ecosystem is limited (Paffenhöfer 1993).

Oithona davisae, which is closely related to $O$. brevicornis and O. aruensis (Nishida \& Ferrari 1983), is distributed in the coastal waters of southwestern Japan (Nishida 1985) and in the Sacramento-San Joaquin estuary, California, USA (Ferrari \& Orsi 1984). It often comprises the most abundant copepod in eutrophic embayments such as Tokyo Bay (Nagasawa \& Marumo 1984, Uye in press), Hiroshima Bay (Uye et al. 1992) and Ariake Bay (Hirota 1990, Hirota \& Tanaka 1985). Among oithonids, the biology of this species has been investigated rather extensively, e.g. on developmental stages (Uchima 1979), seasonal occurrence (Hirota 1979), geographical distribution (Ueda 1991), vertical distribution (Ueda 1987), micro-distribution/swarming (Ueda et al. 1983, Hirota 1990), mating/swimming behavior (Uchima 1985a, b, Uchima \& Hirano 1988, Uchima \& Murano 1988), feeding (Uchima \& Hirano 1986, Uchima 1988), respiration (Hiromi et al. 1988) and predation loss (Uye \& Kayano 1994). However, no detailed studies have been made so far on its reproductive rate (Uchima 1985b).

The objectives of this study were to obtain quantitative information on the seasonal variation in reproduc- 
tive rate of Oithona davisae and to understand how this species multiplies abundantly in eutrophic embayments. Thus, we investigated population density, sex composition, female body size, composition of ovigerous females, egg size, clutch size and inter-clutch period of $O$. davisae in Fukuyama Harbor, a eutrophic inlet in the central part of the Inland Sea of Japan, during the course of a year.

\section{MATERIAL AND METHODS}

Zooplankton samples were taken by oblique tows of a plankton net (mouth diameter: $0.45 \mathrm{~m}_{i}$ length: $2.0 \mathrm{~m}_{\text {i }}$ mesh opening: $62 \mu \mathrm{m}$; with a flowmeter) from the bottom (depth: 7 to $8 \mathrm{~m}$ ) to the surface at intervals of 3 to $5 \mathrm{~d}$ from 7 November 1986 to 8 November 1987 at a station in Fukuyama Harbor (Fig. 1). Samplings were made around the time of full tide during the night (between 17:00 and 7:00 h) to reduce possible variabilities of zooplankton abundance caused by patchy distribution (the night distribution is more homogeneous; Landry 1978, Ujeda 1987) and tidal cycle (Sameoto 1975 , Lee \& McAlice 1979). The samples were preserved immediately in 5 to $10 \%$ formalin-seawater solution. Temperature and salinity at $1 \mathrm{~m}$ depth were measured with a thermo- and salinometer (YSI, Model 33). The surface water $(50$ to $200 \mathrm{ml}$ ) was filtered with a glassfiber filter (Whatman GF/C). Later, the filters were extracted with $90 \%$ aqueous acetone, and chlorophyll a (chl a) concentration was determined with a fluorometer (Turner Designs, Model 10).

Adult females, males and copepodites of Oithona davisae from split sub-samples (1/16 or 1/32 of original samples) were counted under a dissecting microscope, but nauplii were not counted since they were not retained quantitatively by the net we used. Egg sacs either attached to or detached from the female genital segment were also counted. Prosome length of females was measured to the nearest $5 \mu \mathrm{m}$ for 50 individuals of each sample using a video micrometer (Olympus, VM-10). Twenty egg sacs were picked up from each sample, and dissected with fine needles to count the number of eggs per sac. Diameter of eggs, which were taken from the first sample of each month, was measured to the nearest $1 \mu \mathrm{m}$ with an eyepiece micrometer under an inverted microscope. Body carbon weight of a female $\left(C_{A}, \mu g\right)$ was converted from prosome length ( $P L, \mu \mathrm{m})$ with the equation given by Uye (1982):

$$
C_{A}=1.26 \times 10^{-4} \times P L^{1.31} \text {. }
$$

Carbon content of an egg was not measured directly, but converted from egg diameter with the regression equation obtained for 13 copepod species (see 'Results').

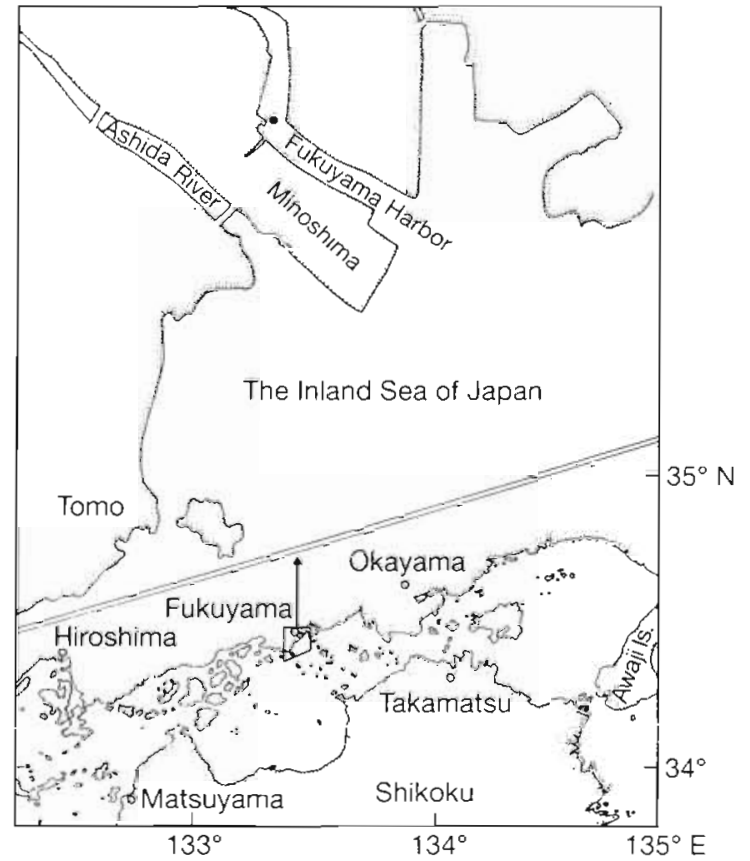

Fig. 1. Location of the sampling station (•) in Fukuyama Harbor, the Inland Sea of Japan.

The time for embryonic development and the time from hatching of egg sacs to production of new ones were investigated in July 1992 using freshly collected ovigerous females from Kure Harbor, a small inlet ca $80 \mathrm{~km}$ west of Fukuyama Harbor with a eutrophication level similar to Fukuyama Harbor. Females were incubated at 5 different temperatures $(10,15,20,25$ and $30 \pm 1{ }^{\circ} \mathrm{C}$ ). At each temperature, 24 specimens were individually incubated in plastic well plates containing ca $5 \mathrm{ml}$ of filtered (with $33 \mu \mathrm{m}$ sieve) natural surface seawater from Kure Harbor which was replaced daily with freshly collected water. Light was not specifically controlled, but natural room light condition was $14 \mathrm{~h}$ light: $10 \mathrm{~h}$ dark. At 2 to $3 \mathrm{~h}$ intervals, specimens were inspected under a dissecting microscope to monitor the production and hatching of their egg sacs. The experiments ran for 5 to $8 \mathrm{~d}$ depending on incubation temperature.

\section{RESULTS}

Environmental variables. Temperature was lowest $\left(8.9^{\circ} \mathrm{C}\right)$ on 2 March and increased to the annual peak $\left(28.2^{\circ} \mathrm{C}\right.$ ) on 11 September (Fig. 2). Salinity ranged from 28.6 to $32.3 \%$, and it was lower and more variable in summer and fall than in winter and spring. Due to effluent from a municipal sewage plant which provides secondary treatment, Fukuyama Harbor is heavily eutrophic. Hence, chl a was high, particularly in sum- 


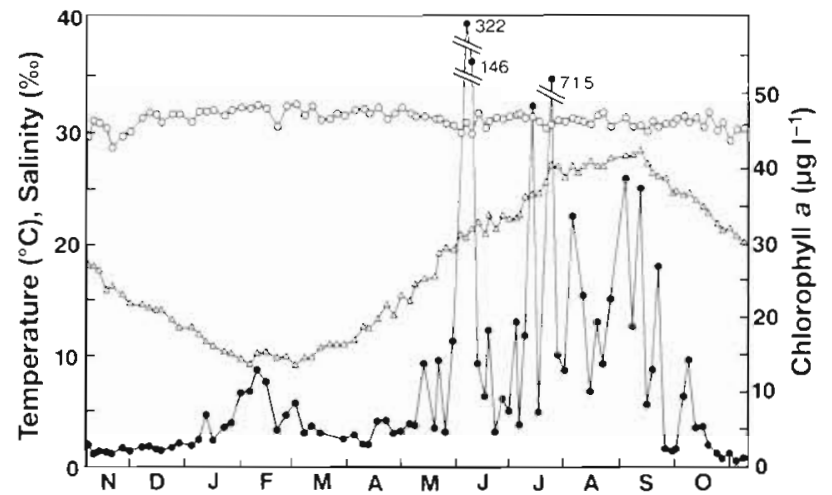

Fig. 2. Seasonal variations in temperature $(\Delta)$, salinity $(0)$ and chlorophyll a concentration $(\bullet)$ in Fukuyama Harbor

mer. Extraordinarily high values were due to occurrence of red tides of Chattonella marina and Heterosigma akashiwo (both Raphidophyceae).

Seasonal variation in population density. Oithona davisae was perennial, but its population density varied remarkably with season (Fig. 3). It was lowest in March and April (mean: $3.5 \times 10^{3}$ females $\mathrm{m}^{-3}, 9.2 \times$ $10^{2}$ males $\mathrm{m}^{-3}$ and $6.5 \times 10^{2}$ copepodites $\mathrm{m}^{-3}$ ). From mid May to mid June, when water temperature rose to ca $20^{\circ} \mathrm{C}, \mathrm{O}$. davisae numbers increased exponentially. The annual peak $\left(24.6 \times 10^{4}\right.$ females $\mathrm{m}^{-3}, 5.49 \times$ $10^{4}$ males $\mathrm{m}^{-3}$ and $29.8 \times 10^{4}$ copepodites $\mathrm{m}^{-3}$ ) was recorded on 18 June. Their density remained high, but fluctuating, until mid July, when it declined to a mid summer minimum. The population increased again in early September, after which it decreased gradually until late winter.

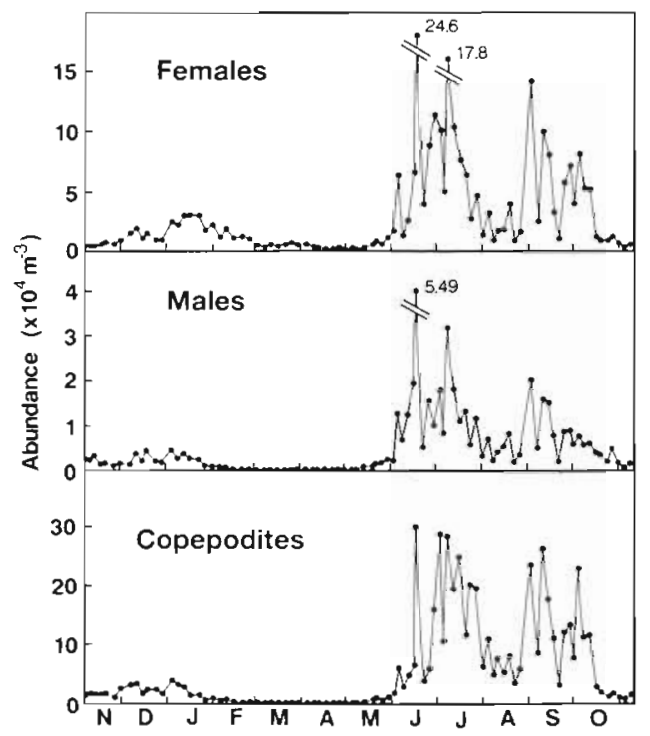

Fig. 3. Oithona davisae. Seasonal variation in abundance of females, males and copepodites in Fukuyama Harbor. Note the difference of scale for each group

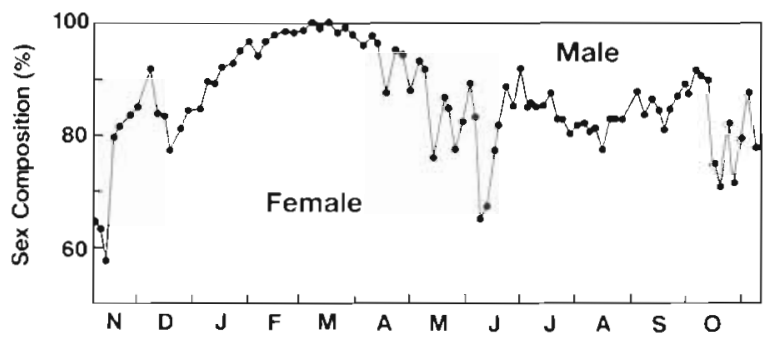

Fig. 4. Oithona davisae. Seasonal variation in sex composition of copepods in Fukuyama Harbor

Seasonal variation in adult sex composition. Females always outnumbered males, the former comprising $85.8 \%$ of the annual mean (Fig. 4). In February and March, adults were almost entirely composed of females (mean: 98.1\%). During the period between June and October, when the population density was high, there were relatively fewer females (mean: $82.7 \%$ ).

Seasonal variation in female body size. Seasonal variations in female prosome length and corresponding body carbon weight are shown in Fig. 5. The size increased, as water temperature decreased, to the maximum (prosome length: $331 \mathrm{\mu m}$; carbon weight: $0.252 \mu \mathrm{g})$ in April, and then it decreased to the minimum (276 $\mu \mathrm{m}$ and $0.199 \mu \mathrm{g}$, respectively) in August. The prosome length $(P L, \mu \mathrm{m})$ was plotted against temperature $\left(T,{ }^{\circ} \mathrm{C}\right)$ (Fig. 6), and the following equation was derived:

$$
P L=344-2.23 T(\mathrm{~N}=90, \mathrm{r}=0.922, \mathrm{p}<0.01) \text {. }
$$

Seasonal variation in composition of ovigerous females. Since Oithona davisae carries a pair of sacs containing nearly equal numbers of eggs, the number of ovigerous females was determined by dividing the number of egg sacs by 2 . The composition of ovigerous females changed irregularly with time; the annual mean was $23.8 \%$ (Fig. 7). The mean composition

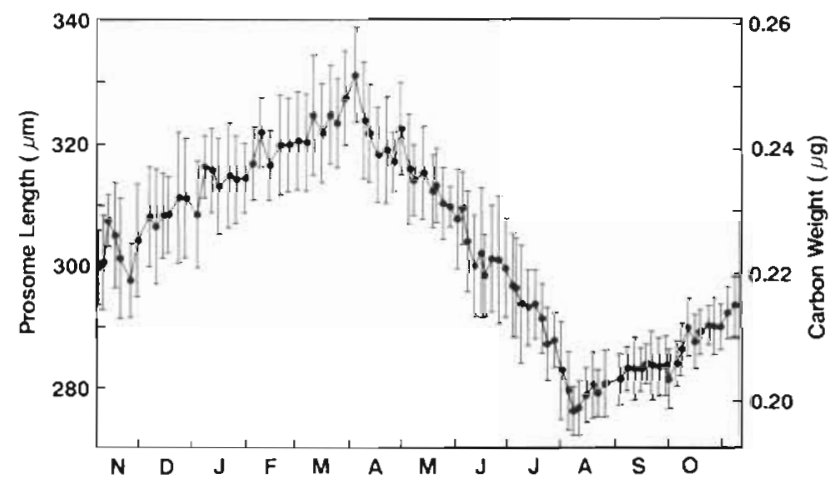

Fig. 5. Oithona davisae. Seasonal variation in mean prosome length and body carbon weight of female copepods in Fukuyama Harbor Vertical lines denote SD 


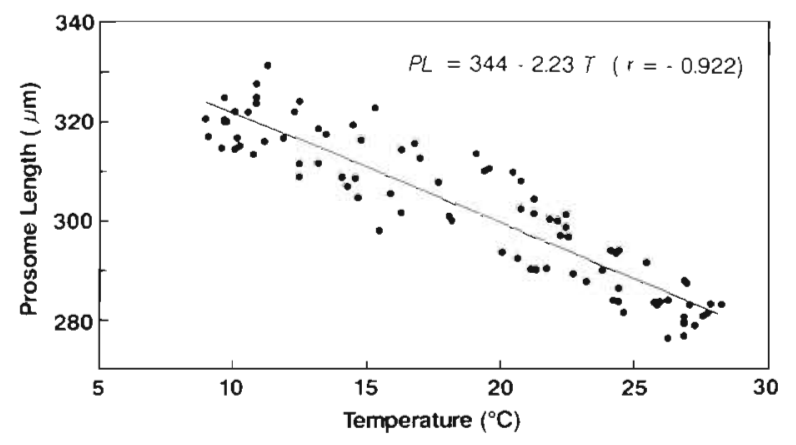

Fig. 6. Oithona davisae. Relationship between water temperature $(T)$ and mean prosome length (PL) of female copepods in Fukuyama Harbor

between April and August (29.6\%) was significantly $(\mathrm{p}<0.01)$ higher than that between December and March $(17.5 \%)$.

Seasonal variation in clutch size. The variation in clutch size, which represents the number of eggs contained in a pair of sacs, was bicyclical (Fig. 8). It was high in fall and early summer, and low in winter and late summer. The annual maximum (28.5 eggs) and minimum (10.9 eggs) clutch size were recorded on 29 May and 29 September, respectively.

From 13 copepod species (see legend of Fig. 9 for species names and references), the composite relationship between egg diameter ( $E D, \mu \mathrm{m})$ and egg carbon content $\left(C_{E}, \mu g\right.$ ) was obtained (Fig. 9). It was expressed by:

$C_{E}=5.32 \times 10^{-8} \times E D^{304}(\mathrm{~N}=13, \mathrm{r}=0.970, \mathrm{p}<0.01)$.

There was no seasonal variation in egg diameter of Oithona davisae; the annual mean was $49.2 \mu \mathrm{m}$ and egg carbon weight was determined from the Eq. (3) as $7.38 \mathrm{ng}$. The specific clutch size was calculated by dividing clutch carbon by female body carbon. It varied biannually, being high in November $(0.78)$ and May (0.99), and low in January and September (both $0.40)$.

Egg development time and duration from hatching to carrying new egg sacs. Among 24 specimens at each experimental temperature, a significant number

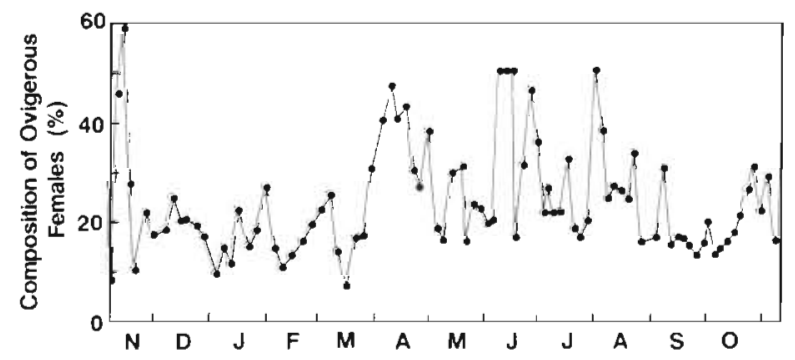

Fig. 7. Oithona davisae. Seasonal variation in composition of ovigerous female copepods in Fukuyama Harbor
Table 1. Oithona davisae. Interval of clutch (i.e. duration from hatching of old egg sacs to the production of new ones) of copepods at various temperatures

\begin{tabular}{|cccc|}
\hline $\begin{array}{c}\text { Tem- Interval of clutch } \\
\text { perature } \\
(\bar{x} \pm \mathrm{CD}, \mathrm{d})\end{array}$ & $\begin{array}{c}\text { No. of females } \\
\text { with now } \\
\text { clutches }\end{array}$ & $\begin{array}{c}\text { Cumulative } \\
\text { no. of } \\
\text { clutches }\end{array}$ \\
\hline 10 & $0.68 \pm 0.18$ & 13 & 13 \\
15 & $0.74 \pm 0.83$ & 13 & 20 \\
20 & $0.79 \pm 1.40$ & 14 & 22 \\
25 & $0.80 \pm 0.94$ & 11 & 19 \\
30 & $0.75 \pm 1.06$ & 10 & 14 \\
Total & $0.75 \pm 1.05$ & 61 & 88 \\
\hline
\end{tabular}

of females did not produce new eggs sacs after hatching of the previous ones. Usually 1 or 2 new clutches were produced per female during our experiment. The time from hatching of egg sacs to the development of new ones was independent of temperature, with a mean of $0.75 \mathrm{~d}$ (Table 1.). However, the time for embryonic development $\left(D_{\mathrm{E}}, \mathrm{d}\right)$ decreased exponentially with increasing temperature $\left(T,{ }^{\circ} \mathrm{C}\right.$ ) (Fig. 10). The best fit was achieved by using the Bělehrádek equation:

$$
D_{\mathrm{E}}=1.31 \times 10^{4} \times(T+12.3)^{-2.60}(\mathrm{r}=0.996) .
$$

Hence, the inter-clutch period $(D, d)$ at a given temperature can be determined by:

$$
D=0.75+D_{\mathrm{E}}
$$

Seasonal variation in egg production rate. The egg production rate for actually breeding Oithona davisae was determined by dividing the mean clutch size by $D$ (Fig. 11). It decreased towards a winter minimum in January and February, when mean egg production rate was 2.6 eggs female $\mathrm{d}^{-1}$. It increased from March to May, remained high in June and July (mean: 11.6 eggs female $\mathrm{e}^{-1} \mathrm{~d}^{-1}$ ) and then decreased again.

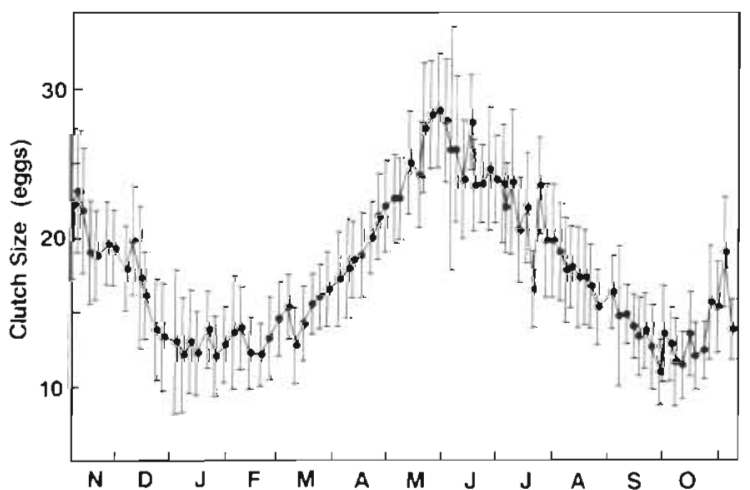

Fig. 8. Othona davisae. Seasonal variation in mean clutch size of ovigerous female copepods in Fukuyama Harbor. Vertical lines denote SD 


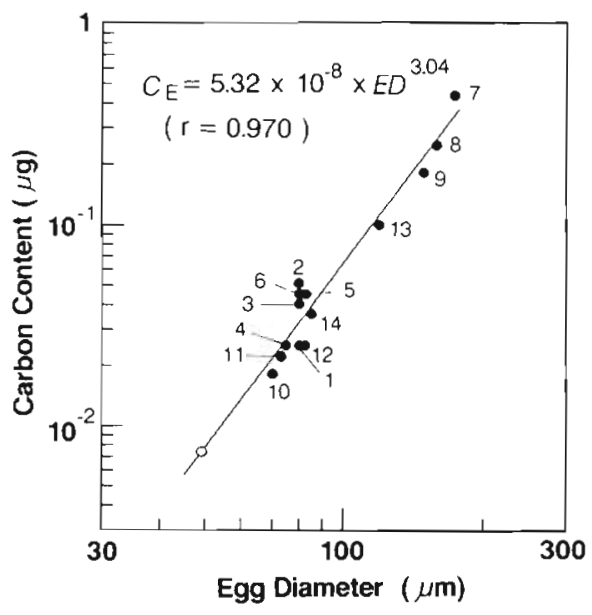

Fig. 9. Relationship between egg diameter (ED) and egg carbon content of copepods $\left(C_{E}\right)$ previously reported 1 : Acartia clausi (Landry 1978); 2: A. hudsonica (Sekiguchi et al. 1980); 3: A. hudsonica (Durbin et al. 1992); 4: A. omorij (Uye 1981); 5: A steveri (Uye 1981); 6: A. tonsa (Kiorboe et al. 1985); 7: Calanus glacialis (Hirche \& Bohrer 1987); 8: C. pacificus (Runge 1984); 9: C. sinicus (Uye unpubl.); 10: Centropages typicus (Dagg 1978); 11. Paracalanus parvus (Checkley 1980); 12: Paracalanus sp. (Uye \& Shibuno 1982); 13: Pseudodiaptomus marinus (Uye et al. 1982); 14: Sinocalanus tenellus (Kimoto et al. 1986). O: Oithona davisae

The average egg production rate $(A E P R$, eggs female ${ }^{-1} \mathrm{~d}^{-1}$ ) of all females (reproductive + unreproductive) was calculated by:

$$
A E P R=\frac{C S \times R F}{T F \times D}
$$

where $C S$ is clutch size (eggs female ${ }^{-1}$ ), and $R F$ and $T F$ are numbers of reproductive and total females (females $\mathrm{m}^{-3}$ ), respectively. As shown in Fig. 7, not all females were ovigerous. Females without egg sacs were expected to include those whose eggs had hatched and had not yet been replaced by new ones

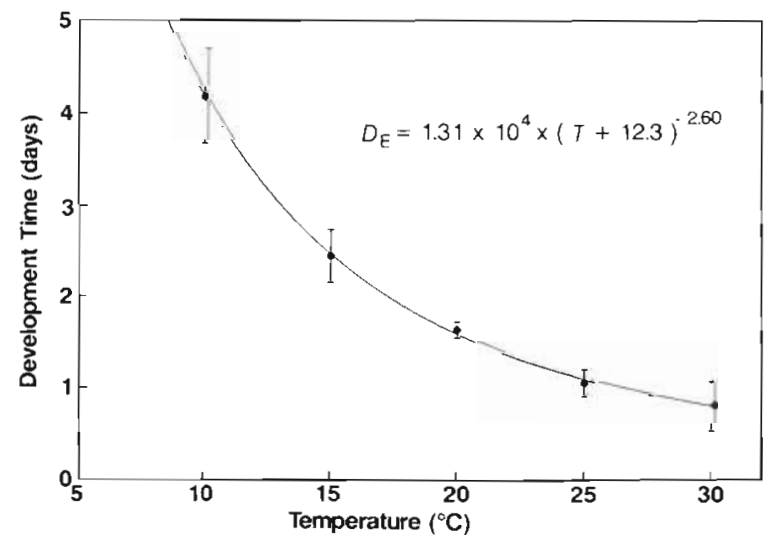

Fig. 10. Oithona davisae. Relationship between temperature (T) and embryonic development time $\left(D_{E}\right)$. Vertical lines denote SD

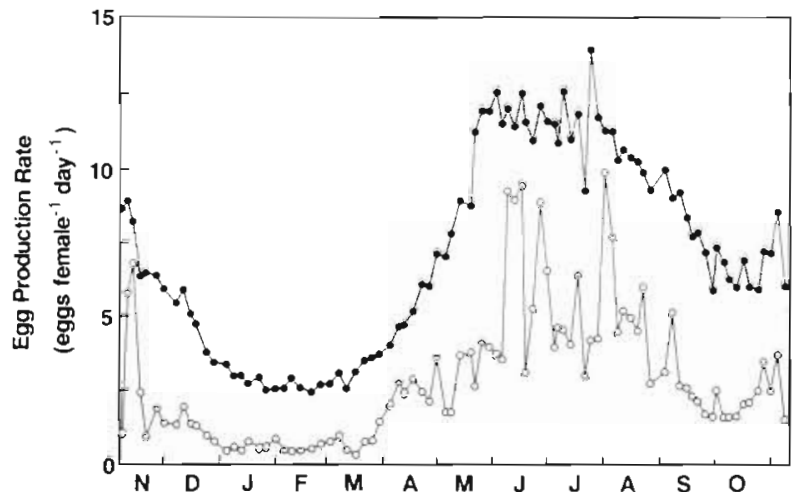

Fig. 11. Oithona davisae. Seasonal variation in egg production rate of breeding females ( $\bullet$ ) and that of total females $(0)$ in Fukuyama Harbor

$(<0.75 \mathrm{~d})$, in addition to infertile females. Then the number of reproductive females can be calculated from:

$$
R F=\frac{O F \times\left(D_{E}+0.75\right)}{D_{E}}
$$

where $O F$ is the number of ovigerous females (females $\mathrm{m}^{-3}$ ).

The population average egg production rate was variable, largely paralleling that of breeding females (Fig. 11). It was low between January and March (mean: 0.6 eggs female ${ }^{-1} \mathrm{~d}^{-1}$ ) and high, but fluctuating, between June and August (mean: 5.6 eggs female ${ }^{-1} \mathrm{~d}^{-1}$ ).

The specific egg production rates were also determined for breeding females and for total females, although they are not presented here. Both showed the

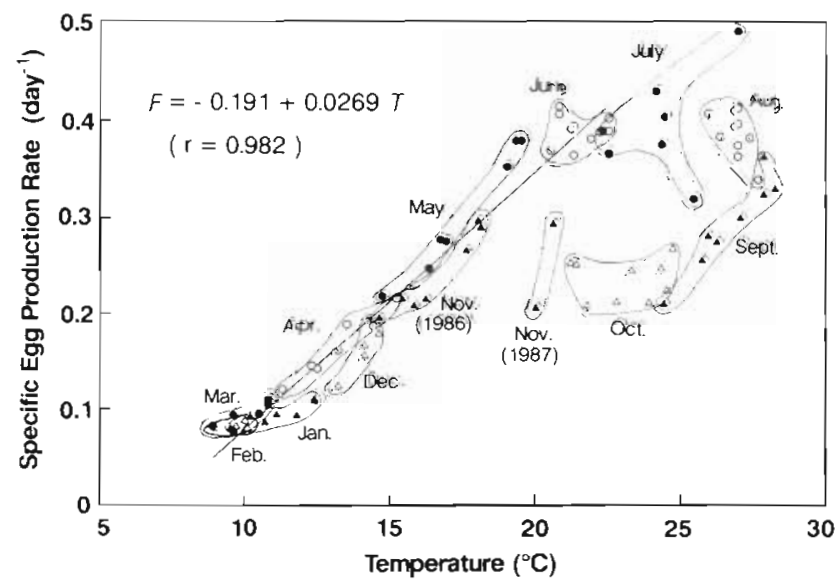

Fig. 12. Oithona davisae. Relationship between water temperature $(T)$ and specific egg production rate of breeding females $(E) .(0,-)$ denote the rates during the temperatureincreasing period and $(\Delta, \mathbf{\Delta})$ those during the temperaturedecreasing period. Solid and open symbols alternate monthly. A regression equation is given for the data between November 1986 and June 1987 , when temperature was less than $22^{\circ} \mathrm{C}$ 


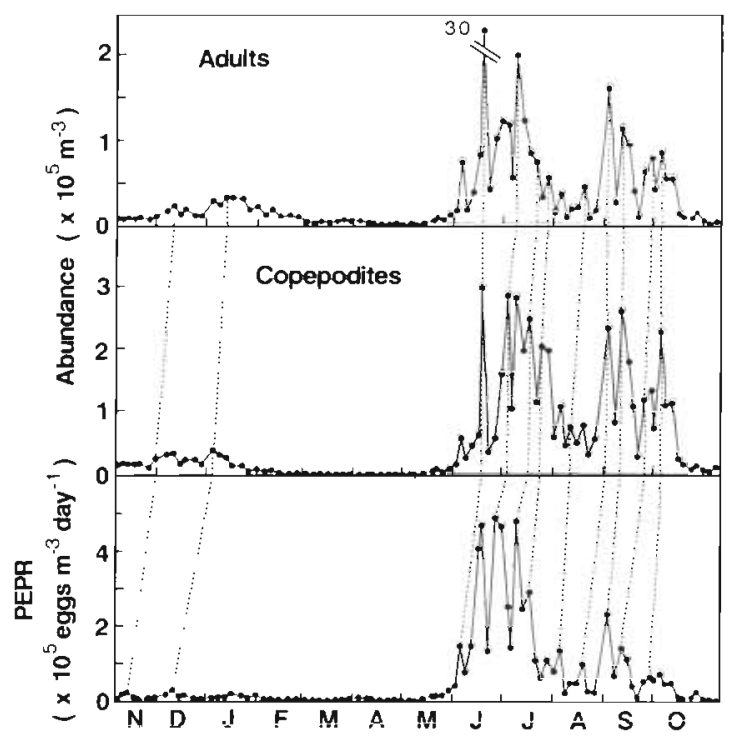

Fig. 13. Oithona davisae. Seasonal variation in population egg production rate (PEPR) and in abundance of copepodites and adults in Fukuyama Harbor. Development of prominent cohorts are traced hy dotted lines

same seasonal pattern as presented in Fig. 11. The former ranged from $0.07 \mathrm{~d}^{-1}$ in February to $0.49 \mathrm{~d}^{-1}$ in July, and the latter ranged from $0.01 \mathrm{~d}^{-1}$ in March to $0.35 \mathrm{~d}^{-1}$ in August.

When the specific egg production rate of breeding females was plotted against temperature (Fig. 12), the rate $\left(F, d^{-1}\right)$ increased linearly with increasing temperature $\left(T,{ }^{\circ} \mathrm{C}\right)$ for females obtained between November 1986 and June 1987, when temperature was less than ca $22^{\circ} \mathrm{C}$ :

$F=-0.191+0.0269 T(\mathrm{~N}=55, \mathrm{r}=0.982, \mathrm{p}<0.01)$.

However, the rate no longer accelerated with temperature elevation for females collected in July and August, and it was reduced significantly between September and November (Fig. 12).

Seasonal variation in population egg production rate. Multiplication of the egg production rate on a population average (Fig. 11) by female density (Fig. 3) gives population egg production rate (eggs $\mathrm{m}^{-3} \mathrm{~d}^{-1}$ ). Approximately 10 prominent peaks of the population egg production rate were observed between June and December, and usually they were followed shortly by peaks of copepodites and adults (Fig. 13).

\section{DISCUSSION}

Since our samplings were performed during nighttime, the distribution of Oithona davisae was thought to be nearly homogeneous throughout the water column (Ueda 1987). Even during daytime, this species does not form swarms (Ueda 1987. Checkley et al. 1992), unlike the subtropical oithonid O. oculata which swarms on the bottom of clear shallow waters (Hamner \& Carleton 1979, Ueda et al. 1983). The maximum population density observed in the present study was enormous $\left(5.98 \times 10^{5}\right.$ adults and copepodites $\left.\mathrm{m}^{-3}\right)$, although it is lower than that recorded in Ariake Bay $\left(1.34 \times 10^{6}\right.$ ind. $\mathrm{m}^{-3}$; Hirota \& Tanaka 1985), indicating that $O$. davisae is adapted to the eutrophic environment of inlet waters. Judging from its high population densities in summer and fall, $O$. davisae is considered to be thermophilic, although its reproductive rate is no longer accelerated at temperatures $>$ ca $22^{\circ} \mathrm{C}$.

One of the characteristic aspects in the reproduction of Oithona davisae was the highly skewed sex ratio for females. In particular, the overwintering population consisted almost entirely of females. In general, copepod males are less tolerant of environmental stress and live for a shorter period than females (Marshall \& Orr 1.972). Consequently, males of $O$. davisae were removed during winter, when the population recruitment rate was extremely low. This, in turn, indicates that the maintenance of the population during unfavorable periods depends on the females' toughness, since this species does not produce resting eggs in its life cycle. Even in the actively reproducing period, i.e. June to October, there were fewer males than females: approximately 1 male versus 5 females. Uchima (1985b) found that 1 copulation is usually enough to fertilize all eggs produced by an $O$. davisae female in her entire life span. We assume that 1 male is capable of copulating with at least 5 females, and hence most females had received spermatophores, although we did not examine their presence/absence on the female genital segment.

It is surprising that females which were actually breeding made up only about one-third of total females. Usually, newly molted females copulate and shortly thereafter commence production of fertilized eggs, although virgin females lay unfertilized eggs in the same mode as that of mated females (Uchima 1985b). Oithona davisae produces on average 3 clutches in her life span (Uchima 1985b), which takes approximately $8 \mathrm{~d}$ at $20^{\circ} \mathrm{C}$. Our unpublished data show that females can live more than $20 \mathrm{~d}$ after their final molt at $20^{\circ} \mathrm{C}$ under laboratory conditions. Although the average life span of females in the field was not known, we assume that most non-breeding females were probably in the post-reproductive period.

If food is sufficient, the egg production rates of copepods are affected by temperature (Uye 1981. Ambler 1986). In Fukuyama Harbor, chl a concentration was generally high, particularly in summer. Uchima \& Hirano (1986) demonstrated that Oithona davisae does 
not feed on diatoms but on flagellates including Chattonella marina and Heterosigma akashiwo, causative species of red tides in Fukuyama Harbor. Although we did not quantify the abundance of flagellates, they were apparently the main component of phytoplankton, at least in summer. Hence, it is assumed that the natural $O$. davisae population was not food limited but exhibited its potential rate of egg production at a given temperature. In order to isolate the effect of temperature on egg production rate, the latter should be expressed in terms of specific egg production rate to offset the effect of female body size. The high coefficient for the regression between the specific egg production rate and temperature (Fig. 12) indicates that temperature determines the variation in egg production rate from November (1986) to June. In July and August, however, the rate no longer accelerated with increasing temperature, but rather decreased. This can be seen as a clockwise shift as the months proceeded on a egg production rate - temperature chart (Fig. 12). As mentioned above, the variation in food supply might not be the reason for this. This was not explained only by females' physiological adversity caused by high temperature, since the reproductive rate in the warmest months, August and September (mean temperature: $26^{\circ} \mathrm{C}$ ), was higher than that in October (mean temperature: $23^{\circ} \mathrm{C}$ ). It is conceivable that adverse environmental impact is most severe upon early nauplii, and adults grown under rigorous conditions may cause some physiological stress. This physiological stress may not be reduced until the temperature is cool enough, i.e. $<$ ca $22^{\circ} \mathrm{C}$. These are the most plausible reasons why the reproductive rates of $O$. davisae were so reduced in the temperature-decreasing period comparing to those in the temperature-increasing period.

Population abundance is a result of the balance between birth rate and death rate, although the actual process of the population dynamics of Oithona davisae was not studied in the present investigation. The variation in population birth rate can be predicted from the population egg production rate (Fig. 13). It was extremely low in winter and spring, increasing exponentially in May and early June, and briefly attained its maximum. There was a remarkable drop in mid summer due to the decrease in the number of adult females. The lobate ctenophore Bolinopsis mikado occurred abundantly in this period, since many comb plates were found in the plankton samples. Hence, the decline of the $O$, davisae population was probably attributed to predation by the ctenophores. The recovery of the $O$. davisae population was observed in early September, when the ctenophores became fewer.

As mentioned earlier, Oithona davisae is a highly successful copepod species in heavily eutrophic inlet waters, where other typical inshore calanoid species such as Acartia omorii, A. erythraea and Paracalanus sp. are present in relatively fewer numbers. In such eutrophic inlets, hypoxia or anoxia prevails at the bottom, especially in summer. The above-mentioned calanoid species shed eggs freely into the water and their eggs often sink to the bottom until they hatch. Their hatching is suppressed by deoxygenation, and prolonged stay in such conditions causes the loss of egg viability (Uye \& Fleminger 1976, Lutz et al. 1992, Roman et al. 1993). On the other hand, $O$ davisae carries eggs in sacs until hatching, and thereby its life can be dissociated from the benthic anoxia. Increase of nano- and microflagellates due to eutrophication (Yamaguchi \& Aruga 1988) may also provide favorable feeding conditions for $O$. davisae. Therefore, the monospecific occurrence of $O$. davisae is thought to be a climax of copepod species succession with the extent of eutrophication (Uye in press).

In conclusion, the egg-sac carrying cyclopoid copepod Oithona davisae is highly adapted to eutrophic inlet environments, where nano-and microflagellates often dominate and recruitment of most calanoids can be negatively affected by benthic anoxia. $O$. davisae is thermophilic; its specific egg production rate monotonically increases with increasing temperature up to ca $22^{\circ} \mathrm{C}$. In mid summer, however, the $O$ davisae population is reduced due to predation by the lobate ctenophore Bolinopsis mikado rather than the reduction of its own reproductive rate. This species barely overwinters in the planktonic form; instead its survival is dependent upon the survival of adult females.

Acknowledgements. We thank $\mathrm{Dr} T$. Onbe for valuable comments. Our gratitude is also extended to Dr P. Tester for critical reading of the manuscript.

\section{LITERATURE CITED}

Ambler, J. W. (1986). Effect of food quantity and quality on egg production of Acartia tonsa Dana from East Lagoon, Galveston, Texas. Estuar. coast. Shelf Sci. 23: 183-196

Checkley, D. M. Jr (1980). The egg production of a marine planktonic copepod in relation to its food supply: laboratory studies. Limnol. Oceanogr. 25: 430-446

Checkley, D. M. Jr, Uye, S., Dagg, M. J., Mullin, M. M., Omori, M., Onbe, T., Zhu, M.-y. (1992). Diel variation of the zooplankton and its environment at neritic stations in the Inland Sea of Japan and the north-west Gulf of Mexico. J. Plankton Res. 14: 1-40

Dagg, M. (1978). Estimated, in situ, rate of egg production for the copepod Centropages typicus (Kroyer) in the New York Bight. J. exp. mar. Biol. Ecol. 34: 183-196

Durbin, E. G., Durbin, A. G., Campbell, R. G. (1992). Body size and egg production in the marine copepod Acartia hudsonica during a winter-spring diatom bloom in Narragansett Bay. Limnol. Oceanogr. 37: 342-360

Ferrari, F. D., Orsi, J. (1984). Oithona davisae, new species, and Limnoithona sinensis (Burckhardt, 1912) (Copepoda: 
Oithonidae) from the Sacramento-San Joaquin estuary, California. J. crust. Biol. 4: 106-126

Hamner, W. H., Carleton, J H. (1979). Copepod swarms: attributes and role in coral reef ecosystem. Limnol. Oceanogr. 24: 1-14

Hirche, H.-U., Bohrer, R. N. (1987), Reproduction of the Arctic copepod Calanus glacialis in Fram Strait. Mar. Biol. 94: $11-17$

Hiromi, J., Nagata, T., Kadota, S. (1988). Respiration of the small planktonic copepod Oithona davisae at different temperatures. Bull. Plankton Soc. Jap. 35: 143-148

Hirota, R. (1979). Seasonal occurrence of zooplankton at a definite station off Mukaishima from July of 1976 to June 1977. Publ. Amakusa mar. Biol. Lab., Kyushu Univ. 5: 9-17

Hirota, R. (1990). Microdistribution of the marine copepod Oithona davisae in the shallow waters of Ariake-kai mud flats, Japan. Mar. Biol. 105: 307-312

Hirota, R., Tanaka, Y. (1985). High abundance of Oithona davisae (Copepoda: Cyclopoida) in the shallow waters adjacent to the mud flats in Ariake-kai, western Kyushu. Bull. Plankton Soc. Jap. 32: 169-170

Kimoto, K., Uye, S., Onbe, T. (1986). Egg production of a brackish-water calanoid copepod Sinocalanus tenellus in relation to food abundance and temperature. Bull. Plankton Soc. Jap. 33: 133-145

Kiørboe, T., Møhlenberg, F., Hamburger, K. (1985). Bioenergetics of the planktonic copepod Acartia tonsa: relation between feeding, egg production and respiration, and composition of specific dynamic action. Mar. Ecol. Prog. Ser. 26: 85-97

Landry, M. R. (1978). Population dynamics and production of a planktonic marine copepod Acartia clausi, in a small temperature lagoon on San Juan Island, Washington. Int. Rev. ges. Hydrobiol. 63: 77-120

Lee, W. Y., McAlice, B. J. (1979). Sampling variability of marine zooplankton in a tidal estuary. Estuar. coast. mar. Sci. 8: 565-582

Lutz, R. V., Marcus, N. H., Chanton, J. P. (1992). Effects of low oxygen concentrations on the hatching and variability of eggs of marine calanoid copepods. Mar. Biol. 114: 241-247

Marshall, S., Orr, A. P. (1972). The biology of a marine copepod. Springer-Verlag, New York

Nagasawa, S., Marumo, R. (1984). The zooplankton community and its abundance in Tokyo Bay. La Mer 22: 277-286

Nishida, S. (1985). Taxonomy and distribution of the family Oithonidae (Copepoda, Cyclopoida) in the Pacific and Indian Oceans. Bull. Ocean Res. Inst., Univ. Tokyo 20: $1-167$

Nishida, S., Ferrari, F. (1983). Redescription of Oithona brevicornis Giesbrecht, and $O$. aruensis Früchtl, new rank, with notes on the status of $O$. spinulosa Lindberg. Bull. Plankton Soc. Jap. 30: 71-80

Paffenhöfer, G.-A. (1993). On the ecology of marine cyclopoid copepods (Crustacea, Copepoda). J. Plankton Res. 15: $37-55$

Roman, M. R., Gauzens, A. L., Rhinehart, W. K., White, J. R (1993). Effects of low oxygen waters on Chesapeake Bay zooplankton. Limnol. Oceanogr. 38: 1603-1614

Runge, J. A. (1984). Egg production of the marine, planktonic copepod, Calanus pacificus Brodsky: Laboratory observations. J. exp. mar. Biol. Ecol. 74: 53-66

Sameoto, D. D. (1975). Tidal and diurnal effects on zooplankton sample variability in a nearshore marine environment.
J. Fish. Res. Bd Can. 32: 847-866

Sekiguchi, H., McLaren, I. A., Corkett, C. J. (1980), Relationship between growth rate and egg production in the copepod Acartia clausi hudsonica. Mar. Biol. 58: 133-138

Uchima, M. (1979). Morphological observation of developmental stages in Oithona brevicornis (Copepoda, Cyclopoida). Bull. Plankton Soc. Jap. 26: 59-76

Uchima, M. (1985a). Copulation in the marine copepod Oithona davisae Ferrari and Orsi. I. Mate discrimination. Bull. Plankton Soc. Jap. 32: 23-30

Uchima, M. (1985b). Copulation in the marine copepod Oithona davisae. 1I. Relationship between copulation and egg-laying. Bull. Plankton Soc. Jap. 32: 31-36

Uchima, M. (1988). Gut content analysis of neritic copepods Acartia omorii and Oithona davisae by a new method. Mar. Ecol. Prog. Ser. 48: 93-97

Uchima, M., Hirano, R. (1986). Food of Oithona davisae (Copepoda: Cyclopoid) and the effect of food concentration at first feeding on the larval growth. Bull. Plankton Soc. Jap. 33: 21-28

Uchima, M., Hirano, R. (1988). Swimming behavior of the marine copepod Oithona davisae: internal control and search for environment. Mar. Biol. 99: 47-56

Uchima, M., Murano, M. (1988). Mating behavior of the marine copepod Oithona davisae. Mar. Biol. 99: 39-45

Ueda, H. (1987). Small-scale ontogenetic and diel vertical distributions of neritic copepods in Mázuni Bay, Japañi Már. Ecol. Prog. Ser. 35: 65-73

Ueda, H. (1991). Horizontal distribution of planktonic copepods in inlet waters. Bull. Plankton Soc. Jap., Spec. Vol.: $143-160$

Ueda, H., Kuwahara, A., Tanaka, M., Azeta, M. (1983). Underwater observations on copepod swarms in temperate and subtropical waters. Mar. Ecol. Prog. Ser. 1.1: 165-1.71

Uye, S. (1981). Fecundity studies on neritic calanoid copepod Acartia clausi Giesbrecht and A. steueri Smirnov: a simple empirical model of daily egg production. J. exp. mar. Biol. Ecol. 50: 255-271

Uye, S. (1982). Length-weight relationships of important zooplankton from the Inland Sea of Japan. J. oceanogr. Soc Jap. 38: 149-158

Uye, S. (in press). Replacement of large copepods by small ones with eutrophication of embayments. Hydrobiologia

Uye, S., Ayaki, Y., Onbe, T. (1992). Seasonal geographical distribution of zooplankton in Hiroshima Bay and its adjacent waters, the Inland Sea of Japan. J. Fac. appl. Biol. Sci. Hiroshima Univ. 31: 99-119

Uye, S., Fleminger, A. (1976). Effect of various environmental factors on egg development of several species of Acartia in Southern California. Mar. Biol. 38: 253-262

Uye, S., Iwai, Y., Kasahara, S. (1982). Reproductive biology of Pseudodiaptomus marnus (Copepoda: Calanoida) in the Inland Sea of Japan. Bull. Plankton Soc. Jap. 29: 25-35

Uye, S., Kayano, Y. (1994). Predatory feeding behavior of Tortanus (Copepoda: Calanoida): life-stage differences and the predation impact on small planktonic crustaceans. J. crust. Biol. 14: 473-483

Uye, S., Shibuno, N. (1992). Reproductive biology of the planktonic copepod Paracalanus sp. in the Inland Sea of Japan. J. Plankton Res. 14: 343-358

Yamaguchi, Y.. Aruga, Y (1988). Transition of primary production in Tokyo Bay. Bull. coast. Oceanogr. 25: 87-95 (in Japanese

Manuscript first received: August 10, 1994

Revised version accepted: November 30, 1994 